\title{
0877 SUICIDE: AN INCREASING PHENOMENON IN ALBANIA
}

E Amursi*, G Qirjako, M Ndrio, E Nelaj, D Anaku, E Toi, J Lakrori Correspondence: Institute of Public Health, Instituti i Shendetit Publik. Rr. "Aleksander Moisiu" Nr. 80 , Tirane, Albania

\subsection{6/ip.2010.029215.877}

The incidence of suicide in Albania is increasing from 1 year to the other. According to the statistics of the State Police there were 146 suicides in the year 2000 and 215 suicides in the year 2007. In the year 2008 the number arrived in 331 suicides in a year. The most affected ages are $16-45$ years old. The method most used is self poisoning from pesticides. They are sold freely and can be purchased by anyone, despite this is forbidden by the law. The data about the suicides are problematic. They are very little detailed on the issues, differ from one institution to another and there is little access on them. The lack of the data creates a barrier for the prevention programs. The suicide cases are reported regularly on the media. The National Institute of Public Health has produced booklets and trained reporters about a responsible reporting of the cases in order to reduce the imitation, but they are generally not respected. The interventions made in order to prevent suicide are not coordinated as in Albania is missing a national strategy on suicide 
prevention. As a conclusion, there is an immediate need to create a unified database of the tentative and realised suicide, to have more research on the field and to draw a national strategy on suicide prevention. The Institute of Public Health is working in these directions. 